\title{
Homeopathic and high dilution preparations for pest management to tomato crop under organic production system
}

\author{
Tatiani A Modolon ${ }^{1}$; Pedro Boff ${ }^{2}$; Mari Inês C Boff' ${ }^{1}$; David José Miquelluti ${ }^{1}$ \\ 'UDESC-CAV, Depto. Agronomia, Av. Luis de Camões 2090, 88520-000 Lages-SC; tatimodolon@hotmail.com; a2micb@cav.udesc.br; \\ a2djm@cav.udesc.br; ${ }^{2}$ EPAGRI, Lab. Homeopatia e Saúde Vegetal, C. Postal 181, 88506-080 Lages-SC; pboff@epagri.sc.gov.br
}

\begin{abstract}
Tomato crops (Solanum lycopersicum) under conventional production system are constantly treated against pest and diseases, with organic synthetic pesticides that are used may cause serious disturbance to environment and human health. This research was carried out in order to study the effect of homeopathic and high dilution preparations on pests and diseases management of tomato crop under organic production system. Two experiments were conducted under field conditions and one in greenhouse. All of them in randomized block design with the cultivar Santa Cruz Kada. The treatments consisted of homeopathic preparations Staphysagria, Arsenicum album, Sulphur, Arnica montana, high dilution preparations of Solanum lycopersicum and Solanum aculeatissimum, at the decimal (DH) or centesimal $(\mathrm{CH})$ scale of hahnemanian high dilution. Bordeaux mixture, cupric preparation, and Bacillus thuringiensis were also included in weight doses. The preparation Arnica montana 12DH increased the tomato yield under field conditions. The damage incidence of small borer was efficiently reduced with applications of Sulphur $12 \mathrm{CH}$ that equalling to $B$. thuringiensis. The same treatment did not reduce the large borers. B. thuringiensis reduced also the septoria leaf spot incidence in the field. In greenhouse, the high dilution preparation of tomato at $12 \mathrm{DH}$ completely suppressed the septoria leaf spot and drastically reduced the same disease at $24 \mathrm{DH}$. The homeopathic and high dilution preparations have the potential to be effective on replacing pesticides that are used on tomato, and could be suitable to fill legal requirement for organic production system.
\end{abstract}

Keywords: Solanum lycopersicum, agro-homeopathy, crop protection.

\begin{abstract}
RESUMO
Manejo fitossanitário do tomateiro com uso de preparados homeopáticos e altas diluições sob sistema orgânico de produção

O tomateiro (Solanum lycopersicum) sob sistema de produção convencional está constantemente sujeito a pragas e doenças, os pesticidas orgânicos sintéticos que são usados podem causar graves perturbações ao meio ambiente e à saúde humana. O objetivo deste trabalho foi avaliar o efeito de preparados homeopáticos e altas diluições no manejo de pragas e doenças da cultura do tomateiro sob sistema orgânico de produção. Foram conduzidos dois experimentos em condições de campo e um experimento em casa de vegetação. Todos eles em delineamento de blocos casualizados com cultivar Santa Cruz Kada. Os tratamentos constituíram-se dos preparados homeopáticos Staphysagria, Arsenicum album, Sulphur, Arnica montana, preparados em altas diluições de Solanum lycopersicum e Solanum aculeatissimum, nas escalas decimal (DH) e centesimal $(\mathrm{CH})$ de dinamização hahnemaniana. Calda bordalesa, calda cúprica e Bacillus thuringiensis também foram incluídos em doses ponderais. $\mathrm{O}$ preparado de Arnica montana 12DH proporcionou a maior produção de frutos de tomateiro a campo. Danos pela broca pequena foram eficientemente reduzidos com aplicação de Sulphur $12 \mathrm{CH}$, igualando a B. thuringiensis. O mesmo tratamento não foi eficiente para reduzir a incidência das brocas grandes. $B$. thuringiensis reduziu a incidência de septoriose a campo. Em casa de vegetação, o preparado em alta diluição de tomateiro na 12DH suprimiu completamente a incidência de septoriose, enquanto que na $24 \mathrm{DH}$ a doença foi drasticamente reduzida. O uso de preparados homeopáticos e preparados em altas diluições tem potencial para ser eficaz na substituição de pesticidas que são utilizados na cultura do tomate e poderia ser adequado para preencher requisito legal para o sistema orgânico de produção.
\end{abstract}

Palavras-chave: Solanum lycopersicum, agro-homeopatia, manejo fitossanitário.

(Recebido para publicação em 7 de outubro de 2010; aceito em 27 de dezembro de 2011)

(Received on October 7, 2010; accepted on December 27, 2011)

$\mathrm{T}^{\mathrm{s}}$ omato (Solanum lycopersicum) is an important vegetable crop widely cultivated in Santa Catarina state. Tomatoes are also excellent sources of nutrition including potassium, vitamin $\mathrm{C}$, and various carotenoids and phytochemicals such as polyphenols (Yoshimura et al., 2010). They can be consumed as fresh and processed food such as salad and juice. The conventional cultivation of tomato has required a lot of pesticides to control pests and diseases meanly due to the lack of adequate resistance in the available cultivars and the intensive system throughout heavy mineral fertilization that is currently used. The application of synthetic substances, namely agrochemicals to protect plants against pests and diseases, has threatened the environment, the farmer, and the consumers health (Almeida et al., 2009). Studies carried out by National Agency of Sanitary Surveillance (ANVISA), throughout the project of residue analysis of agrochemicals on food, demonstrated that $32.5 \%$ of fresh tomato samples from the market showed levels of pesticide residues much higher than was allowed by legal regulations (ANVISA, 2009). The analysis detected also active substances forbidden to be used on tomato crops such as allethrin, chlorpyrifos, methamidophos, cyproconazole and aldicarb (ANVISA, 2009). 
Environment-sound technologies and pesticide-free foods are often a concern to consumers elsewhere. The claim of consumers pushes farmers to move from conventional agriculture practices into sustainable crop systems supported by ecological principles with minimal hazardous effects (Boff, 2008). In this way, organic production systems are being developed and highly stimulated by public policies (Brazil, 2008). Nevertheless, the ecological transition of agriculture still demands frequent intervention to solve crop management problems such as insects and diseases (Khatounian, 2001).

The use of high dilution preparations according to homeopathic science is one of the best possibilities that can fill both requirements: (a) to overcome phytossanitarian problems and (b) to restore the biological dynamic equilibrium (Boff, 2008). Active preparations at high dilution works on plants by improving their own physiological state, inducing resistance and favouring multiple biological interactions in the way that healthy plants are tolerant to pests and diseases and promptly response for optimal production (Bonato, 2007).

The homeopathic knowledge can be appropriated by farmers and it would be very suitable for family farmers that will intend to conduct an ecological/organic based production system. The use of homeopathic preparations in agricultural systems is legally provided in Brazil by the organic production regulations throughout normative instruction $n^{\circ}$ 64, on the December 18, 2008 (Brasil, 2008). Homeopathic preparations have showed effective results to manage several pests and diseases on plants and consequently farmer had also better yields and healthy life. Gonçalves et al. (2009) could control trips on onion crops by using ground shells at 6 and $30 \mathrm{CH}$ (centesimal hahnemanian dilutions). Rossi et al. (2007) demonstrated that potato plants produced more tubers when treated with Datura metel $12 \mathrm{CH}$ and Bryonia alba $12 \mathrm{CH}$ than the control one. Toledo (2009) showed reduction of $43 \%$ and $73 \%$ in severity of early blight (Alternaria solani) on tomato by spraying Ferrum sulphuricum 12 and $30 \mathrm{CH}$, respectively. Higher level of essential oil was also produced by mint plants treated with Sulphur at 6, 12, 24, and 30CH (Bonato et al., 2009). Boff (2008) pointed out that homeopathic preparations obtained from local resources, called biotherapics, particularly the nosodes that are made from parts of the own plant or insect/ pests, can provide the farmers a simple, versatile, and cheap tool to quickly overcome farm problems. Another way to choose suitable homeopathic preparation to treat plants is from what is described in the homeopathic materia medica (Vijnovsky, 1980). Despite the fact that very little is known about the mode of action of high dilution preparations, we are able to measure its effects throughout experimental studies (Brizzi et al., 2005).

This research was carried out in order to evaluate the effect of homeopathic and high dilution preparations on crop protection of tomatoes cultivated under organic production systems.

\section{MATERIAL AND METHODS}

Experiments were conducted at Experimental Station of Epagri, Lages (2748'S, 50¹9'W, 931 meters altitude), Santa Catarina State, Brazil, during crop cycles 2008/2009 and 2009/2010. The soil has been classified as Haplumbrept (Embrapa, 1999). Tomato seeds of cultivar Santa Cruz Kada were supplied by organic farmers associated to the Ecological Centre, municipality of Ipê, Rio Grande do Sul state, Brazil.

The research consisted of two field experiments and one greenhouse assay. The experimental design was in randomized blocks with four replications for the first field experiment and greenhouse assay, and three replications for the second field experiment. The soil where the field experiments were carried out was previously prepared by planting, in the winter Fagopyrum tataricum and Vicia sativa for producing biomass that remained on the soil. $11 \mathrm{t} \mathrm{ha}^{-1}$ of cattle manure compost were added. Field plots were composed by 10 plants in double row $(0.5 \mathrm{~m}$ between plants and $1 \mathrm{~m}$ between rows). Each tomato plant, with one stalk, was vertically sustained by a bamboo stick. The greenhouse plot consisted of one 27-day old tomato plantlet, transplanted into $5 \mathrm{~L}$ plastic vase filled with soil, sand and cattle manure at $2: 1: 1$ proportion, respectively. The greenhouse assay was conducted with $60 \pm 5 \%$ relative humidity and temperature of $25 \pm 5^{\circ} \mathrm{C}$.

Treatments for the field crop cycle 2008/2009 consisted of homeopathic preparations of Staphysagria, Arsenicum album, and Sulphur at 12CH (centesimal dilution), bordeaux mixture at $0.3 \%$, Bacillus thuringiensis at $1 \mathrm{~mL} \mathrm{~L}^{-1}$ of commercial product Dipel ${ }^{\circledR}$, and nonintervention plot. In the field crop cycle 2009/2010 and greenhouse assay, the treatments were: high dilution preparations of Solanum lycopersicum (tomato x cultivar Santa Cruz Kada) and Solanum aculeatissimum (wild specie), homeopathic preparations of Arnica montana and Sulphur, all 12DH and 24DH (decimal dilution); Bordeaux mixture at $0.3 \%$, cupric formulation EEC at 50 ppm (formulated with grape vinegar, seed flax, and copper sulphate), and non-intervention plot. The homeopathic and high dilution preparations were chosen according to current literature on high dilution research and by doing analogies with homeopathic materia medica (Vijnovsky, 1980). Arnica is reported for physical damage that tomato could have along its growing cycle. Staphysagria is indicated to improving plant resistance against pests and diseases (Bonato, 2009). Arsenicum album was reported to supress spore germination of fungi, whereas Sulphur supress the growing of mycelium (Sinha \& Singh, 1983; Casali et al., 2009). The high preparations of Solanum spp. were included on base of the related ancestral of the crop.

Ten homeopathic preparations were prepared according to the methodology described in the Brazilian Homeopathic Pharmacopeia (Farmacopéia Homeopática Brasileira, 1997). The matrix (stock preparations) of Staphysagria, Arsenicum album, Sulphur and Arnica montana were bought from homeopathic pharmacy in Lages, Santa Catarina State. The high dilution preparations of $S$. lycopersicum and $S$. aculeatissimum were prepared 
from mother tincture obtained by the maceration of green leaves and stalks of the respective plant in alcohol, during 15 days.

The application of the treatments for the three experiments was performed in double-blind, where neither the applicator nor the evaluator knew the identity of the treatments. The treatments were identified by codes and being known just after processing the data.

The dose of field experiments was $10 \mathrm{~mL} \mathrm{~L}^{-1}$ of homeopathic preparations and high dilution preparation into pure water. The field sprays were applied with knapsack sprayer (Guarany ${ }^{\circledR}$ ) using hollow-cone nozzle with an application rate of $600 \mathrm{~L} \mathrm{ha}^{-1}$, in the morning period. Weekly spray applications were done from December 11, 2008 (37 days after transplanting) until March 19, 2009 for the first experiment and from December 21, 2009 (27 days after transplanting) until February 22, 2010 for the second field experiment. All applications were stopped seven days before the last harvest.

In the greenhouse assay, treatments were applied with the dose of $60 \mathrm{~mL}$ $\mathrm{L}^{-1}$ with an individual garden sprayer (Brudden ${ }^{\circledR}$ ) and stopping spraying just before run-off. Applications were performed every 3 days. They started in the $2^{\text {nd }}$ and stopped in the $67^{\text {th }}$ day after transplanting. The dose was six time higher than that one used in the field for trying to have a quick response due to a short crop cycle under greenhouse conditions. The irrigation was interrupted during spraying time until 30 minutes after that. When $70 \%$ of tomato plants reached the $7^{\text {th }}$ true leaf, about 14 days after transplanting, detached leaves from field tomato crop were introduced among the tomato plant pots as a source of $S$. lycopersici inoculum. The inoculum source consisted of trays having three tomato leaves with typical symptoms of $S$. lycopersici disease. They presented 30 to $50 \%$ of the leaf area occupied by sporulation symptoms of $S$. lycopersici. In the time of conducting the experiment, $S$. lycopersici was the predominant tomato disease, which may have been also influenced by the cultivar. The relative humidity reached $70 \%$, at the time of conducting the experiment. Evaluations in the field experiments consisted of disease incidences, fruit damage by insects and yield of fruit at harvest. The incidence of the most frequent disease, septoria leaf spot, was estimated by counting the number of leaves that presented typical symptoms of Septoria lycopersici infection. The harvest was weekly by picking the ripe fruits. The collected fruits were counted, weighed, and measured their diameter. Tomato fruits damaged by insects were separated into categories as fruit damaged by large borers (Helicoverpa zea, Spodoptera frugiperda and Spodoptera eridania) and by small borer (Neoleucinodes elegantalis).

The incidence and severity of septoria leaf spot and fruit yield in greenhouse assay were also evaluated. The disease severity was considered as the proportion of diseased leaflets in relation to the total of the plant. Fruits were counted and weighted and the number of bunches of flowers and fruits were registered per plant-plot at the $70^{\text {th }}$ day after transplanting. The crop cycle was than interrupted for operational limitations and practical reasons. Data analysis was performed according to experimental design throughout GLM and MIXED procedure of SAS ${ }^{\circledR}$ software package (Version 9.1) and the means were compared by Tukey test at 5\% significance (Littel et al., 2006). To fill statistical assumptions, the variables number of fruits and number of bunches in the greenhouse assay had added the constant value of one (1) and after that elevated to square root. The values of septoria leaf spot incidence $(\%)$, and number of fruits damaged by insects from field experiments were transformed to arc-sine after having the data added the constant value of three eighth (3/8) and elevated to square root. All transformations were done according to data descriptive analysis and results were presented on original values. It was not possible to do the transformation from the crop cycle 2009/2010 data, concerning the variable of area under the curve of septoria leaf spot, due to the lack of regular heterogeneity of variance and non-normality. In this case, we performed the Freedman test using software R (R Development Core Team, 2008).

\section{RESULTS AND DISCUSSION}

Tomato plants treated with Staphysagria $12 \mathrm{CH}$ yielded fruits with higher diameter than those without intervention but it did not increase the weigh per plant.

Sulphur $12 \mathrm{CH}$ significantly reduced the number of fruits damaged by the small borer (Neoleucinodes elegantalis) (Table 1) but not the number of fruits damaged by the large borers. Sulphur $12 \mathrm{CH}$ did not differ from Bacillus thuringiensis kurstaki (Dipel ${ }^{\circledR}$ ). Dipel is recommended by organic certifiers as being the best product to control large and small tomato borers (Dias, 1992). The effect of Sulphur on small borers was not confirmed in the second experiment, crop cycle 2009/2010 (Table 2). It can be argued that the dilution order makes the difference, since in 2008/2009 Sulphur was prepared by centesimal dilutions (CH) whereas in 2009/2010 was at decimal dilutions (DH). Also, none of the other high dilution preparations on decimal dilution order could reduce the fruit damage by borers (Table $2)$. However, it can differ from one homeopathic preparation to another and further studies are needed. In fact, centesimal and decimal dilutions are independent methods and different effects would be expected from them as indicated by Farmacopeia Homeopatica Brasileira (1997). The effect of high dilution preparations on insect pests was also reported by Deboni (2009). This author obtained 83 to $100 \%$ reduction on Acanthoscelides obtectus progeny when bean grains were treated with nosode of the own adult of $A$. obtectus.

Tomato plants treated by Sulphur $24 \mathrm{DH}$ in greenhouse conditions showed higher number of bunches but it did not differ from the nonintervention plot (Table 3). An increase in biomass is frequently reported by using homeopathic preparations. However, as stated by Bonato (2007), it is not always in linear response and the experiment design must include several possibilities of potential level 
Table 1. Fruit production and incidence of borers and septoria leaf spot in tomato plants treated with homeopathic and high dilution preparations under organic production systems (produção de frutos e incidência de brocas e septoriose em tomateiro tratado com preparados homeopáticos e altas diluições sob sistema orgânico de produção). Lages, EPAGRI, 2008/2009.

\begin{tabular}{lccccc}
\hline Treatments & $\begin{array}{c}\text { Fruit } \\
\text { (g/plant) }\end{array}$ & $\begin{array}{c}\text { Fruit } \\
\boldsymbol{0}(\mathbf{m m})\end{array}$ & $\begin{array}{c}\text { Large borers*1 } \\
\text { (\% of damaged fruits) }\end{array}$ & $\begin{array}{c}\text { Small borers*2 } \\
\text { of damaged fruits) }\end{array}$ & $\begin{array}{c}\text { Septoria leaf spot*3 } \\
\text { (\% of leaves) }\end{array}$ \\
\hline Staphysagria 12CH & $774.52 \mathrm{a}$ & $47.07 \mathrm{a}$ & $7.07 \mathrm{a}$ & $4.92 \mathrm{ab}$ & $8.32 \mathrm{a}$ \\
$\begin{array}{l}\text { Bacillus thuringiensis } \\
\left(1 \mathrm{~mL} \mathrm{~L}^{-1}\right)\end{array}$ & $669.57 \mathrm{ab}$ & $45.43 \mathrm{ab}$ & $5.42 \mathrm{~b}$ & $2.42 \mathrm{~b}$ & $0.18 \mathrm{~b}$ \\
Bordeaux mixture (0.3\%) & $617.65 \mathrm{ab}$ & $44.86 \mathrm{~b}$ & $6.32 \mathrm{ab}$ & $5.55 \mathrm{ab}$ & $3.37 \mathrm{ab}$ \\
Without intervention & $612.22 \mathrm{ab}$ & $44.71 \mathrm{~b}$ & $7.05 \mathrm{ab}$ & $7.72 \mathrm{a}$ & $3.88 \mathrm{ab}$ \\
Arsenicum album 12CH & $535.35 \mathrm{~b}$ & $43.41 \mathrm{~b}$ & $9.55 \mathrm{a}$ & $5.87 \mathrm{ab}$ & $6.76 \mathrm{ab}$ \\
Sulphur 12CH & $528.75 \mathrm{~b}$ & $44.21 \mathrm{~b}$ & $5.57 \mathrm{ab}$ & $3.05 \mathrm{~b}$ & $2.51 \mathrm{ab}$ \\
\hline CV (\%) & 27.15 & 3.81 & 24.12 & 46.52 & 7.71 \\
\hline
\end{tabular}

Means followed by the same letter, in the column, did not differ from each other by Tukey test ( $\mathrm{p}>0.05$ ) (médias seguidas da mesma letra na coluna não diferem entre si pelo teste de Tukey $(\mathrm{p}>0.05)$ ); ${ }^{\mathrm{ns}}=$ Not significant by Tukey test $(\mathrm{p}>0.05)$ (não significativo pelo teste de Tukey $(\mathrm{p}>0.05))$; ${ }^{*}$ Original values. For statistical analysis, data were transformed to arc-sin after having the data added the constant value of three eighth (3/8) and elevated to square root (médias originais. Para análise estatística, os dados foram transformados para arco-seno, depois de terem sido adicionados o valor da constante de três oitavos (3/8) e elevado a raiz quadrada). ${ }^{1}$ Helicoverpa zea, Spodoptera frugiperda, Spodoptera eridania; ${ }^{2}$ Neoleucinodes elegantalis; ${ }^{3}$ Proportion of leaves with disease symptoms (Septoria lycopersici) (proporção de folhas com sintomas da doença (Septoria lycopersici)).

Table 2. Profitability, incidence of borers and septoria leaf spot in tomato treated with homeopathic and high dilution preparations under organic production systems (rentabilidade, incidência de brocas e septoriose em tomateiro tratado com preparados homeopáticos e altas diluições). Lages, EPAGRI, 2009/2010.

\begin{tabular}{|c|c|c|c|c|c|}
\hline Treatments & $\begin{array}{c}\begin{array}{c}\text { Fruit } \\
\text { (g/plant) }\end{array} \\
\end{array}$ & $\begin{array}{c}\text { Fruit diameter } \\
(\mathrm{mm})\end{array}$ & $\begin{array}{c}\text { Large borers } * 1 \\
(\% \text { of damaged fruits) (\% }\end{array}$ & $\begin{array}{l}\text { Small borers*2 } \\
6 \text { of damaged fruits) }\end{array}$ & $\begin{array}{l}\text { Septoria leaf spot } \\
\text { (AUDPC) }^{3}\end{array}$ \\
\hline Arnica montana $12 \mathrm{DH}$ & $1491.56 \mathrm{a}$ & $45.21 \mathrm{a}$ & $6.73^{\text {ns1 }}$ & $2.60^{\mathrm{ns} 1}$ & $478.35^{\text {ns2 }}$ \\
\hline Sulphur 24DH & $1226.70 \mathrm{ab}$ & $44.61 \mathrm{a}$ & 7.62 & 1.77 & 357.90 \\
\hline Sulphur 12DH & $1211.83 \mathrm{ab}$ & $44.43 \mathrm{a}$ & 6.85 & 2.22 & 228.02 \\
\hline $\begin{array}{l}\text { Solanum aculeatissimum } \\
\text { 12DH }\end{array}$ & $1211.46 \mathrm{ab}$ & $44.76 \mathrm{a}$ & 8.37 & 5.05 & 264.73 \\
\hline $\begin{array}{l}\text { Cupric formulation EEC } \\
(50 \mathrm{ppm})\end{array}$ & $1159.80 \mathrm{ab}$ & $43.57 \mathrm{ab}$ & 6.29 & 2.94 & 490.92 \\
\hline Arnica montana 24DH & $1135.86 \mathrm{ab}$ & $44.33 \mathrm{a}$ & 6.31 & 3.66 & 416.58 \\
\hline Tomato 24DH & $1056.03 \mathrm{~b}$ & $44.11 \mathrm{a}$ & 5.63 & 2.94 & 1694.17 \\
\hline $\begin{array}{l}\text { Bordeaux mixture } \\
(0.3 \%)\end{array}$ & $1055.16 \mathrm{~b}$ & $43.38 \mathrm{ab}$ & 8.63 & 3.12 & 71.75 \\
\hline Tomato 12DH & $1025.33 \mathrm{~b}$ & $43.53 \mathrm{ab}$ & 7.97 & 3.42 & 223.28 \\
\hline Without intervention & $1004.36 \mathrm{~b}$ & $44.15 \mathrm{a}$ & 8.35 & 1.76 & 1275.58 \\
\hline $\begin{array}{l}\text { Solanum aculeatissimum } \\
\text { 24DH }\end{array}$ & $844.56 \mathrm{~b}$ & $42.06 \mathrm{~b}$ & 7.65 & 3.85 & 61.65 \\
\hline
\end{tabular}

CV $(\%)$

7.71

4.23

19.94

33.27

Means followed by the same letter, in the column, did not differ from each other by Tukey test ( $\mathrm{p}>0.05)$ (médias seguidas da mesma letra na coluna não diferem entre si pelo teste de Tukey $(\mathrm{p}>0.05))$; ${ }^{\mathrm{n} l}=$ Not significant by Tukey test $(\mathrm{p}>0.05)$ (não significativo pelo teste de Tukey $(\mathrm{p}>0.05)) ;{ }^{\text {ns } 2}=$ Not significant by Freedman test $\left({ }^{\mathrm{ns} 2}=\right.$ não significativo pelo teste de Freedman); ${ }^{*}$ Original values. For statistical analysis, data were transformed to arc-sin after having the data added the constant value of three eighth (3/8) and elevated to square root (médias originais. Para análise estatística, os dados foram transformados para arco-seno depois de ter os dados adicionados o valor da constante de três oitavos $(3 / 8)$ e elevado à raiz quadrada). ${ }^{1}$ Helicoverpa zea, Spodoptera frugiperda, Spodoptera eridania $;{ }^{2}$ Neoleucinodes elegantalis; ${ }^{3} \mathrm{AUDPC}=$ Area under disease progress curve (Septoria lycopersici) (AACPD = área abaixo da curva do progresso da doença (Septoria lycopersici)).

and frequency. Carvalho et al. (2003) found that the level biomass production of Tanacetum parthenium treated by Arnica montana 1DH was higher than produced by plants treated by Arnica montana 3DH. Despite the fact that
Sulphur 12DH and 24DH reduced the septoria leaf spot incidence, it was not significant probably due to high variance of data (Table 2). However, Toledo (2009) observed reduction levels of $35 \%$ and $17 \%$ of Alternaria solani incidence when applied Sulphur $12 \mathrm{CH}$ and $30 \mathrm{CH}$, respectively. Sinha \& Singh (1983) reported $100 \%$ efficiency of Sulphur $200 \mathrm{CH}$ on inhibition of the aflatoxin produced by Aspergillus parasiticus.

Tomato plants treated with Arnica 
montana $12 \mathrm{DH}$ showed increase of fruit weight at the level of $48.5 \%$ comparing to non-intervention (Table 2). Arnica montana $12 \mathrm{DH}$ and $24 \mathrm{DH}$ provided similar results in all evaluated variables. However, Arnica montana 12DH and 24DH did not differ from the control in relation to fruits damaged by borers and septoria leaf spot incidence in the field experiment. Under greenhouse conditions, Arnica montana at $12 \mathrm{DH}$ and 24DH did not differ from the control for the number of fruit bunches, but it reduced the incidence and severity of septoria leaf spot (Table 3). Carvalho et al. (2003) observed that Arnica montana 1DH applied to $T$. parthenium plants increased $28 \%$ in biomass in comparison to plants treated with water.

Solanum aculeatissimum 24DH applied under field conditions could reduce the septoria leaf spot incidence on tomato plants, expressed by the curve under disease progress (ACDP), when compared to non-intervention. However, the high value of variance did not allow to detect significant differences among treatments $(\mathrm{p}>0.05)$ (Table 2). On the other hand, tomato plants under greenhouse conditions treated by nosodes of $S$. aculeatissimum
12DH and 24DH showed less incidence and severity of septoria leaf spot than non treated plants (Table 3 ). Rolim et al. (2005) observed that the nosode of A. solani at $30 \mathrm{CH}$ and $60 \mathrm{CH}$ reduced the severity of the own late blight on tomato plants under greenhouse conditions. The reduction of severity of A. solani on tomato was also reported by Toledo (2009) that used Ferrum sulphuricum $12 \mathrm{CH}$ and $30 \mathrm{CH}$. The use of homeopathic preparations from wild ancestral plant species (Euchlaena mexicana) was studied by Almeida (2003). This author observed deleterious effect on Spodoptera frugiperda larvae feed on corn plants when applied Euchlaena at $6 \mathrm{CH}$. In our studies, the high dilution preparations related specie S. aculeatissimum to tomato family did not affect genus pests nor the tomato yield (Table 2).

The tomato 12DH suppressed 100\% infection of septoria leaf spot. At 24DH potential level, the tomato reduced also the incidence and severity of septoria leaf spot under greenhouse conditions in relation to other treatments (Table 3). However, plants treated by this high dilution preparation showed to delay the fruit maturation (data not presented).
Moreover, tomato 24DH reduced more than $90 \%$ of septoria leaf spot severity in comparison to Bordeaux mixture that is largely used by organic farmers (Table $3)$. This trend also occurred in plants treated with the cupric formulation EEC. However, these results were not consistent under field conditions, where the tomato at $12 \mathrm{DH}$ or $24 \mathrm{DH}$ did not affect the tomato yield nor the insect damages and disease infection (Tabela 2). However, it seems that centesimal dilution $(\mathrm{CH})$ would better discriminate the high dilution treatments on tomato crops than decimal dilution order (DH) and further studies should be done on that. On the other hand, attention should be devoted to high dilution effects from own tomato plants, which showed a potential to reduce septoria leaf spot under greenhouse conditions.

Unexpected result was observed by applying Arsenicum album $12 \mathrm{CH}$. Tomato fruits produced by plants treated with this preparation were highly damaged by Helicoverpa zea, $S$. frugiperda, and S. eridania (Table 1). This can be interpreted as pathogenic response meanwhile the high dilution preparations stimulate host reaction in which come out artificial disorders

Table 3. Fruit production and occurrence of septoria leaf spot in tomato plants cultivated in greenhouse and treated with homeopathic and high dilution preparations (produção de frutos e ocorrência de septoriose em tomateiro cultivado em casa de vegetação e tratados com preparados homeopáticos e altas diluições). Lages, EPAGRI, 2010.

\begin{tabular}{|c|c|c|c|c|}
\hline \multirow{2}{*}{ Treatments } & \multicolumn{2}{|c|}{ Septoria leaf spot (AUDPC) $)^{1}$} & \multicolumn{2}{|c|}{ Production (n $\% /$ plant $)^{2}$} \\
\hline & Incidence & Severity & Bunches of flowers & Fruit \\
\hline Tomato $12 \mathrm{DH}$ & $0.00 \mathrm{e}$ & $0.00 \mathrm{c}$ & $2.00 \mathrm{ab}$ & $0.00^{\mathrm{ns}}$ \\
\hline Tomato 24DH & $60.40 \mathrm{e}$ & $118.75 \mathrm{c}$ & $2.48 \mathrm{ab}$ & 1.69 \\
\hline Arnica montana 24DH & $611.14 \mathrm{~d}$ & $1813.28 \mathrm{~b}$ & $1.95 \mathrm{ab}$ & 0.83 \\
\hline Arnica montana $12 \mathrm{DH}$ & $625.17 \mathrm{~d}$ & $2286.97 \mathrm{ab}$ & $2.23 \mathrm{ab}$ & 1.61 \\
\hline Sulphur 12DH & $631.93 \mathrm{~d}$ & 1929.16 b & $1.40 \mathrm{~b}$ & 2.70 \\
\hline Solanum aculeatissimum 12DH & $748.31 \mathrm{~d}$ & $1475.72 \mathrm{~b}$ & $2.48 \mathrm{ab}$ & 1.36 \\
\hline Sulphur 24DH & $760.79 \mathrm{~cd}$ & $1532.20 \mathrm{~b}$ & $3.24 \mathrm{a}$ & 2.03 \\
\hline Solanum aculeatissimum 24DH & $896.40 \mathrm{~cd}$ & $1296.97 \mathrm{~b}$ & $2.00 \mathrm{ab}$ & 1.62 \\
\hline $\begin{array}{l}\text { Cupric formulation } \\
\text { ppm) }\end{array}$ & $1247.44 \mathrm{bc}$ & $1948.49 \mathrm{~b}$ & $1.73 \mathrm{ab}$ & 0.65 \\
\hline Bordeaux mixture $(0.3 \%)$ & $1557.66 \mathrm{~b}$ & $1981.06 \mathrm{~b}$ & $2.48 \mathrm{ab}$ & 2.03 \\
\hline Without intervention & $2855.46 \mathrm{a}$ & $3190.35 \mathrm{a}$ & $2.23 \mathrm{ab}$ & 1.12 \\
\hline $\mathrm{CV}(\%)$ & 22.17 & 28.34 & 9.63 & 26.98 \\
\hline
\end{tabular}

Means followed by the same letter, in the column, did not differ from each other by Tukey test ( $\mathrm{p}>0.05)$ (médias seguidas da mesma letra, na coluna não diferem entre si pelo teste de Tukey $(\mathrm{p}>0.05))$. ${ }^{\mathrm{ns}}=$ Not significant by Tukey test $(\mathrm{p}>0.05)$ (não significativo pelo teste de Tukey $(\mathrm{p}>0.05)) ;{ }^{1}$ AUDPC $=$ Area under disease progress curve (Septoria lycopersici) $($ AACPD = área abaixo da curva do progresso da doença (Septoria lycopersici)). ${ }^{2}$ The crop cycle was interrupted at $70^{\text {th }}$ days after transplanting for operational limitations and practical reasons. Original values. For statistical analysis, data were transformed to $\sqrt{(\mathrm{x}+1,0)}$ (o ciclo da cultura foi interrompido aos 70 dias após o transplante por limitações operacionais e razões práticas. Médias originais. Para análise estatística, os dados foram transformados em $\sqrt{(\mathrm{x}+1,0)})$. 
(Bonato, 2007). Homeopathic pathogenic responses are manifestations from the interaction between the organisms and high dilution preparations, resulting in a temporary pathologic figure. Baiocco et al. (2008) observed also similar results by using Staphysagria $65 \mathrm{CH}$ on kale that increased the number of winged aphids. In our studies, Staphysagria $12 \mathrm{CH}$ increased also infection of Septoria lycopersici by comparing disease incidence with the control (Table 1). Nevertheless, the results are not the same for different conditions, as demonstrate by Rolim et al. (2005), who reported reduction on $A$. solani severity on tomato by applying Staphysagria $30 \mathrm{CH}$. Inducing resistance could be one of the mode of action of high dilution on plants against diseases. This mechanism is well known with application of several chemical composts and it has been suggested by Bonato (2007) that would work on plants treated by high dilution preparations.

Despite the fact that $B$. thuringiensis is a traditional biological control product used against caterpillars, it did not differ from other treatments in our studies. Moreover, B. thuringiensis presented significant effect on reducing the incidence of septoria leaf spot (Table 1). Biological control agents namely bacteria and some fungus act throughout antibiosis that means they produce such kind of metabolites adverse to the other organism, being insects or parasites (Knaak et al., 2009). The antibiosis action of $B$. thuringiensis kurstaki on S. lycopersici is suggested because the low incidence of the infection on plants treated by the bacteria was consistent (Table 1). These results are supported by Knaak et al. (2007), that found the proteins Cryl Ab e Cry1Ac produced, respectively, by $B$. thuringiensis thuringiensis isolate 407 and $B$. thuringiensis kurstaki HD73 , to reduce the mycelia growth of Pyricularia grisea, Rhizoctonia solani, Fusarium oxysporum, and F. solani. Resmuska \& Pria (2007) verified also reduction growth on Monilinia fructicola and Sclerotium rolfsii mycelia by $B$. thuringiensis and they prevented sclerotia formation.

Bordeaux mixture at $0.3 \%$ could reduce more than $50 \%$ of septoria leaf spot incidence comparison to the control plants in greenhouse conditions (Table 3 ). This result was consistent in the field experiments, where the septoria leaf spot incidence was reduced by $90 \%$ on the crop cycle 2009/2010 (Table 2). Nevertheless, Bordeaux mixture was not better than high dilution preparation to manage diseases and pests on tomato crops.

In conclusion, we may state that high dilution preparations have the potential to replace Bordeaux mixture, a traditional formulation largely used by organic farmers. Despite its well known insecticidal action, $B$. thuringiensis showed to have deleterious effect on phytopathogenic fungus. The high dilution Sulphur $12 \mathrm{CH}$ can be used to protect tomato fruits against the small borer damage.

\section{ACKNOWLEDGEMENTS}

The authors thank MCT/CTHIDRO/CNPq and FAPESC/FAPEU that through the project "Rede Guarani/ Serra Geral" Conv. 16261/10-2 provided financial support for this research. They are also grateful to the field workers and technicians at Experimental Station and Homeopathy and Plant Health Laboratory of Epagri-Lages. The first author thanks CAPES for the scholarship during MSc studies and the second one thanks $\mathrm{CNPq}$ for sponsoring as PQ-researcher.

\section{REFERENCES}

ALMEIDA A. 2003. Preparados homeopáticos no controle de Spodoptera frugiperda (JE Smith, 1797) (Lepidoptera: Noctuidae) em milho. Viçosa: UFV. 55p. (Dissertação mestrado).

ALMEIDA VES; CARNEIRO FF; VILELA NJ. 2009. Agrotóxicos em hortaliças: segurança alimentar, riscos socioambientais e políticas para promoção da saúde. Tempus, Actas em Saúde Coletiva 4: 84-89.

ANVISA. 2009. Programa de análise de resíduos de agrotóxicos em alimentos - PARA. Disponível em http://portal.anvisa.gov.br/ wps/portal/anvisa/home/agrotoxicotoxicologia Acesso em 02 de agosto de 2010.

BAIOCCO TM; MAPELLI NC; CREMON C; NEVES LG. 2008. Efeito da homeopatia Staphysagria na incidência de Brevicoryne brassicae (L.) (Sterrnorhyncha: Aphididae em couve. In: CONGRESSO BRASILEIRO DE OLERICULTURA, 48. Resumos... Maringá: ABH (CD-ROM).

BOFF P (coord). 2008. Agropecuária saudável: da prevenção de doenças, pragas e parasitas à terapêtica não residual. Lages: Epagri; Udesc 80p.

BONATO CM (coord). 2009. Homeopatia na agricultura. Maringá: Grupo de estudos de homeopatia na agricultura alternativa da universidade estadual de Maringá - UEM. 40p.

BONATO CM. 2007. Homeopatia em modelos vegetais. Cultura Homeopática 21: 24-28.

BONATO CM; PROENÇA GT; REIS B. 2009. Homeopathic drugs arsenicum album and sulphur affect the growth and essential oil content in mint (Mentha arvensis L.). Acta Scientiarum. Agronomy 31: 101-105.

BRASIL. 2008. Instrução Normativa $N^{\circ} 64$ de 18 de dezembro de 2008. Aprova o regulamento técnico para os sistemas orgânicos de produção animal e vegetal. Diário da República Federativa do Brasil, Brasília, DF, 19 de dezembro de 2008 - Seção I, p21.

BRIZZI M; LAZZARATTO L; NANI D; BORGUINI F; PERUZZI M; BETTI L. 2005. A bio-statistical insight into the $\mathrm{As}_{2} \mathrm{O}_{3}$ high dilution effects on the rate and variability of wheat seedling growth. Forsch Komplementärmed Klass Naturheilkd 12: 277-283.

CARVALHO LM; CASALI VWD; CECON PR; SOUZA MA; LISBOA SP. 2003. Efeito de potências decimais da homeopatia de Arnica montana sobre plantas de artemísia. Revista Brasileira de Plantas Medicinais 6: 46-50.

CASALI VWD; ANDRADE FMC; DUARTE ESM. 2009. Acologia de altas diluições. Viçosa: UFV - Departamento de Fitotecnia. $537 \mathrm{p}$.

DIAS JMCS. 1992. Produção e utilização de bioinseticidas bacterianos. Pesquisa Agropecuária Brasileira 27: 59-76.

DEBONI TC. 2009. Preparados homeopáticos e fitoterápicos no manejo de Acanthoscelides obtectus Say, 1831 (Coleoptera: Bruchidae) em feijão armazenado. Lages: UDESC-CAV. 79p. (Dissertação mestrado).

EMBRAPA. 1999. Sistema brasileiro de classificação de solos. Rio de Janeiro: Embrapa Solos. $412 \mathrm{p}$.

FARMA COPÉIA HOMEOPÁ TICA BRASILEIRA. 1997. São Paulo: Atheneu. $118 \mathrm{p}$.

GONÇALVES PAS; BOFF P; BOFF MIC. 2009. Preparado homeopático de calcário de conchas no manejo de tripes e produtividade de cebola. Agropecuária Catarinense 22: 91-93.

KHATOUNIAN CA. 2001. A reconstrução ecológica da agricultura. Botucatu: Ed. Agroecológica. 348p.

KNAAK N; AZAMBUJA AO; LUCHO APR; BERLITZ DL; FIUZA LM. 2009. Interações de Bacillus thuringiensis e o controle de fitopatógenos. Biotecnologia Ciência $\varepsilon$ Desenvolvimento 38: 48-53.

KNAAK N; ROHR AA; FIUZA LM. 2007. In vitro effect of Bacillus thuringiensis strains and cry proteins in phytopathogenic fungi 
of paddy rice-field. Brazilian Journal of Microbiology 38: 1-7.

LITTEL RC; MILLIKEN GA; STROUP WW; WOLFINGER RD; SCHABENBERGER O. 2006. SAS ${ }^{\circledR}$ for Mixed Models. SAS Institute Inc.: Cary, NC, USA. 834p.

R DEVELOPMENT CORE TEAM (2008). $R$ : A language and environment for statistical computing. Austria: R Foundation for Statistical Computin. Disponível em http:// www.r-project.org

REMUSKA AC; PRIA MD. 2007. Efeito de Bacillus thuringiensis e Trichoderma sp. no crescimento de fungos fitopatogênicos. UEPG Ciências Exatas Terra, Ci. Agr. Eng., 13: 31-36.

ROLIM PRR; TOFOLI JG; DOMINGUES RJ; ROSSI F. 2005. Preparados homeopáticos no controle da pinta preta do tomateiro.
In: CONGRESSO BRASILEIRO DE OLERICULTURA, 45. Resumos... Fortaleza: ABH (CD-ROM).

ROSSI F; AZEVEDO FILHO JA; MELO PCT; AMBROSANO EJ; GUIRADO N; SCHAMMASS EA. 2007. Cultivo orgânico de batata com aplicação de preparados homeopáticos. In: CONGRESSO BRASILEIRO DE AGROECOLOGIA, 5. Resumos... Rev. Bras. de Agroecologia, 2: 937-940.

SINHA KK; SINGH P. 1983. Homeopathic drugs inhibitors of growth and aflatoxin production by Aspergillus parasiticus. Indian Phytopathology 36: 356-357.

STATISTICAL ANALYSIS SYSTEM, Institute Inc $\circledR_{2}$ 2003. SAS Ver. 9.1 3 SAS Institute Inc.: Cary, NC, USA. Lic. UDESC.
TOLEDO MV. 2009. Fungitoxicidade contra Alternaria solani, controle da pinta preta e efeito sobre o crescimento do tomateiro (Lycopersicum esculentum Mill) por medicamentos homeopáticos. Marechal Cândido Rondon: UNIOESTE. 94p (Dissertação mestrado).

VIJNOVSKY B. 1980. Tratado de matéria médica homeopática. Rio de Janeiro: Editora: Mukunda. v1, 2 e 3.

YOSHIMURA M; TOYOSHI T; SANO A; IZUMI T; FUJII T; KONISHI C; INAI S; MATSUKURA C; FUKUDA N; EZURA H; OBATA A. 2010. Antihypertensive effect of a $\gamma$-aminobutyric acid rich tomato cultivar 'DG03-91' in spontaneously hypertensive rats. Journal of Agricultural and Food Chemistry 58:615-619. 